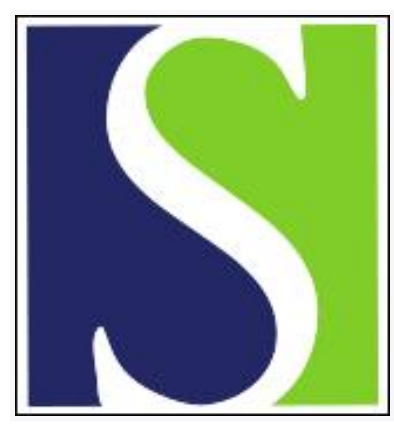

Scand J Work Environ Health 1999;25(5):422-429

https://doi.org/10.5271/sjweh.455

Issue date: Oct 1999

Occupational risk factors for lung cancer among young men

by Kreuzer M, Pohlabeln H, Ahrens W, Kreienbrock L, Brüske-Hohlfeld I, Jöckel K-H, Wichmann HE

Key terms: asbestos exposure; case-referent study; occupation; young adult

This article in PubMed: www.ncbi.nlm.nih.gov/pubmed/10569462

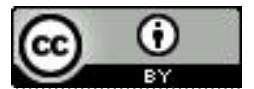




\title{
Occupational risk factors for lung cancer among young men
}

\author{
by Michaela Kreuzer, PhD, ${ }^{1,2}$ Hermann Pohlabeln, MSc, ${ }^{3}$ Wolfgang Ahrens, PhD, ${ }^{3,4}$ Lothar Kreienbrock, \\ PhD, ${ }^{1,5}$ Irene Brüske-Hohlfeld, MD, ${ }^{1}$ Karl-Heinz Jöckel, PhD, ${ }^{4}$ H Erich Wichmann, MD
} Kreuzer M, Pohlabeln H, Ahrens W, Kreienbrock L, Brüske-Hohlfeld I, Jöckel K-H, Wichmann HE. Occupational
risk factors for lung cancer among young men. Scand J Work Environ Health 1999;25(5):422-429.

\begin{abstract}
Objectives This study evaluated whether occupational exposure plays a role for lung cancer at a very young age. Methods In a pooled analysis of 2 German case-referent studies including 3498 incident cases among men and 3541 male population referents, a group of men ( 187 cases and 202 referents) aged $\geq 45$ years was compared with a group of 2186 cases and 2146 referents aged 55-69 years. Occupational exposure to known (A list) or suspected (B list) lung carcinogens was assessed using job and industry codes, and exposure to asbestos was assessed using job-specific supplementary questionnaires. A conditional logistic regression was used to calculate the odds ratios (OR) and to control for smoking.

Results Asbestos exposure showed an odds ratio (OR) of 2.39 [95\% confidence interval (95\% CI) $1.41-4.04]$ for the younger group and 1.46 (95\% CI 1.24-1.72) for the older group. Having ever worked in a job belonging to the A list as compared with never working in an A- or B-list job was associated with a significantly increased risk for the younger (OR 2.06, 95\% CI 1.03-4.12) and older (OR 1.35, 95\% CI 1.10-1.65) groups, adjusted for asbestos. Lung cancer risk for those working in A-list jobs at a very young age (under 16 years) was increased in the younger group (OR 6.14, 95\% CI 1.41-28.01) in contrast to the older group (OR 1.19,95\% CI 0.91-1.63).

Conclusion Occupational risk factors play an important role for lung cancer among young men. Early age at first exposure may favor an early age of the onset of lung cancer.
\end{abstract}

Key terms asbestos exposure, case-referent study, occupation, young adults.

Lung cancer is the leading cause of death from cancer among men in Germany, with a crude mortality rate of 72.9 per 100000 of the population in 1993 (1). About $2 \%$ of these lung cancer deaths occurred at an age of below 45 years. There is little knowledge about causes for the early onset of lung cancer. Excessive exposure to carcinogenic substances or genetic susceptibility are discussed in this respect. A few studies on young lung cancer patients identified smoking as an important risk factor $(2-7)$, and 3 recent studies indicated a higher genetic susceptibility among younger cases ( $7-9$ ) than among older cases. Occupational risk factors for lung cancer at a young age have not yet been investigated in detail.

Doll \& Peto (10) estimated that about $15 \%$ of lung cancer cases are attributable to occupational risk factors for men over all ages in the United States. This estimation has been shown to be comparable for West Germany (11). In a pooled analysis of 2 case-referent studies, conducted between 1988 and 1994 in Germany, both with a detailed assessment of occupational history, we investigated a group of younger cases and referents, aged 45 years or less. The aim was to evaluate whether occupational exposure plays a causal role for the development of lung cancer at a young age. In addition we compared the results with those for an older case-referent group (55 to 69 years of age) from the same study, to look at possible age-dependent differences in exposure and lung cancer risk.

Young worker populations are of particular interest for retrospective case-referent studies on lung cancer and occupation because exposure histories are not so far back in the past and the number of jobs the person has had is

1 Institute of Epidemiology, GSF - National Research Centre for Environment and Health, Neuherberg, Germany.

2 Institute of Radiation Hygiene, Federal Office of Radiation Protection, Neuherberg, Germany.

3 Bremen Institute for Preventional Research and Social Medicine, Bremen, Germany.

4 Institute for Medical Informatics, Biometry and Epidemiology, University Clinics of Essen, West German Cancer Registry, Essen, Germany.

5 Institute for Biometry, Epidemiology and Data Processing, Hannover Veterinary School, Hannover, Germany.

Reprint requests to: Dr Michaela Kreuzer, Federal Office of Radiation Protection, Institute of Radiation Hygiene, Ingolstädter Landstr 1,85764 Neuherberg, Germany. [E-mail: mkreuzer@bfs.de] 
lower as compared with that of older cases. Occupational exposures among young workers tend, therefore, to be more accessible, more accurate, and less confounded by other exposures.

\section{Subjects and methods}

\section{Study design}

The data were derived from 2 large case-referent studies conducted in Germany. One of the studies, the BIPS study (Bremen Institute for Preventional Research and Social Medicine) on lung cancer and occupation, was carried out between 1988 and 1993 in Bremen and Frankfurt and the surrounding areas. It included 1004 cases and the same number of population referents, individually matched for region, gender, and age ( \pm 5 years) (12). The other study on lung cancer and indoor radon was conducted by the GSF (GSF National Research Centre for Environment and Health) from 1990 to 1996 (13). It covered parts of Northrhine-Westphalia, Rhineland Palatinate, eastern Bavaria, the Saar region, and Thuringia and Saxony in eastern Germany. Since this study was still in progress when the analysis began, only a subset of interviews carried out up to the end of 1994 was used for the pooled analysis. It consisted of 3180 cases and 3249 population referents, matched by frequency for region, gender, and age (5-year categories).

Incident cases of lung cancer were selected from study clinics located in the defined study areas of each study center. The inclusion criteria were a histologically or cytologically confirmed primary tumor and a date of diagnosis within 3 months before the interview. Population referents were randomly selected from population registers (BIPS study, part of GSF study) or by random digit dialing (part of GSF study). The inclusion criteria that applied to both the cases and referents were current residence within the study area and an age of less than 75 years (GSF study) or year of birth after 1912 (BIPS study). Further details on both studies have been published elsewhere $(7,12,13)$.

For the present study we restricted the analysis to men. The subjects were defined as young when they were aged $\leq 45$ years, as was the case in a previous analysis (7). For purposes of comparison, an older age group consisting of subjects 55 to 69 years of age was defined. The subjects aged 46 or 54 years were excluded so that the 2 age groups would be clearly separated, and those over 69 were excluded because their recall for past exposures might be less accurate than that of the subjects from the younger age group. The response rate for eligible cases was $68 \%$ in the BIPS study and $77 \%$ in the GSF study. The corresponding rates for the population referents were
$69 \%$ and $41 \%$, respectively. For both the cases and referents in both centers the response rates were slightly higher for younger cases and referents than for older ones.

Table 1 shows some basic characteristics of the study population. Altogether 187 young cases and 202 young referents were included, while the older group consisted of 2186 cases and 2146 referents. The mean age was 41 years in the younger group of cases and referents and 62 years in the older group. The youngest lung cancer patient was 29 years of age.

\section{Exposure assessment}

Standardized questionnaires were applied by trained interviewers to determine basic demographic characteristics in addition to a detailed lifelong smoking history in a face-to-face interview. Occupational exposures were evaluated on the basis of a lifelong job history and a supplementary, job-specific questionnaire (14).

All occupations during a lifetime were evaluated in a concept of job periods, a new period being defined as change of job or industry. For each work period, the job title and industry were coded according to standard German classifications $(15,16)$. A list of jobs, branches and industries in which a carcinogenic risk for lung cancer has been confirmed (A list) and a list of occupations reported to present a lung cancer risk, but for which the currently available results of risk assessment cannot be considered definitive (B list), was matched as closely as possible to the 3-digit code for job titles and the 5-digit code for departments within industries. This allocation is based on international standard classifications of occupations [ISIC (17)] and industries [ISCO (18)]. Both lists originate from Simonato \& Saracci (19) and Boffetta et al (20) and were recently iuvised by Ahrens \& Merletti (21). If a subject had worked for at least 6 months in an occupation on the A list (B list) at any time in his life, he was defined as exposed in an A list occupation (B list occupation). Table 2 lists in detail all occupations and industries classified as belonging to the $\mathrm{A}$ list, and table 3 gives those belonging to the $\mathrm{B}$ list. Asbestos exposure was assessed on the basis of 17 job-specific supplementary questionnaires in a semi-automated way, these questionnaires yielding exposure values expressed in calendar years of exposure and duration in days (12, $14,22,23)$. To be defined as an asbestos-exposed worker a subject had to have worked for a period of at least 6 months in a particular occupation.

Subjects were defined as smokers if they had ever smoked regularly (at least 1 cigarette per day, 4 cigarillos per week, 3 cigars or 3 pipes per week) for a period of at least 6 months. In a concept of smoking periods, based on changes in either quantity or type of tobacco product, we ascertained dates of start and end, the quantity and type of tobacco consumption (cigars, cigarettes, pipes, cigarillos). This information enabled us to con- 
Table 1. Characteristics of both age groups by case-referent status. (BIPS = Bremen Institute for Preventional Research and Social Medicine, GSF = National Research Centre for Environment and Health)

\begin{tabular}{|c|c|c|c|c|c|c|c|c|}
\hline & \multicolumn{4}{|c|}{$\leq 45$ years } & \multicolumn{4}{|c|}{$55-69$ years } \\
\hline & \multicolumn{2}{|c|}{ Cases } & \multicolumn{2}{|c|}{ Referents } & \multicolumn{2}{|c|}{ Cases } & \multicolumn{2}{|c|}{ Referents } \\
\hline & $\mathbf{N}$ & $\%$ & $N$ & $\%$ & $N$ & $\%$ & $\mathrm{~N}$ & $\%$ \\
\hline All study & 187 & 100.0 & 202 & 100.0 & 2186 & 100.0 & 2146 & 100.0 \\
\hline $\begin{array}{l}\text { BIPS study } \\
\text { GSF study }\end{array}$ & $\begin{array}{r}40 \\
147\end{array}$ & $\begin{array}{l}21.4 \\
78.6\end{array}$ & $\begin{array}{r}35 \\
167\end{array}$ & $\begin{array}{l}17.3 \\
82.7\end{array}$ & $\begin{array}{r}477 \\
1709\end{array}$ & $\begin{array}{l}21.7 \\
78.3\end{array}$ & $\begin{array}{r}423 \\
1723\end{array}$ & $\begin{array}{l}19.7 \\
80.3\end{array}$ \\
\hline \multicolumn{9}{|l|}{ Family status } \\
\hline $\begin{array}{l}\text { Single } \\
\text { Married } \\
\text { Widowed } \\
\text { Divorced } \\
\text { Unknown }\end{array}$ & $\begin{array}{r}20 \\
144 \\
1 \\
22 \\
-\end{array}$ & $\begin{array}{r}10.7 \\
77.0 \\
0.5 \\
11.8 \\
-\end{array}$ & $\begin{array}{r}21 \\
165 \\
- \\
16 \\
-\end{array}$ & $\begin{array}{r}10.4 \\
81.7 \\
- \\
7.9 \\
-\end{array}$ & $\begin{array}{r}70 \\
1919 \\
115 \\
80 \\
2\end{array}$ & $\begin{array}{r}3.2 \\
87.8 \\
5.2 \\
3.7 \\
0.1\end{array}$ & $\begin{array}{r}51 \\
1946 \\
88 \\
61 \\
-\end{array}$ & $\begin{array}{r}2.4 \\
90.7 \\
4.1 \\
2.8 \\
-\end{array}$ \\
\hline \multicolumn{9}{|l|}{ Education } \\
\hline $\begin{array}{l}<9 \text { years } \\
9 \text { years } \\
10-11 \text { years } \\
\geq 12 \text { years } \\
\text { Other }\end{array}$ & $\begin{array}{r}4 \\
124 \\
34 \\
25 \\
-\end{array}$ & $\begin{array}{r}2.1 \\
66.3 \\
18.2 \\
13.5 \\
-\end{array}$ & $\begin{array}{r}1 \\
79 \\
55 \\
67 \\
-\end{array}$ & $\begin{array}{r}0.5 \\
39.1 \\
27.2 \\
33.2 \\
-\end{array}$ & $\begin{array}{r}55 \\
1783 \\
213 \\
130 \\
5\end{array}$ & $\begin{array}{r}2.5 \\
81.6 \\
9.3 \\
6.4 \\
0.2\end{array}$ & $\begin{array}{r}43 \\
1451 \\
300 \\
351 \\
1\end{array}$ & $\begin{array}{r}2.0 \\
67.6 \\
14.0 \\
16.4 \\
0.0\end{array}$ \\
\hline \multicolumn{9}{|l|}{ Smoking status } \\
\hline $\begin{array}{l}\text { Lifelong nonsmoker } \\
\text { Ever smoker }\end{array}$ & $\begin{array}{r}10 \\
177\end{array}$ & $\begin{array}{r}5.3 \\
94.7\end{array}$ & $\begin{array}{r}49 \\
153\end{array}$ & $\begin{array}{l}24.3 \\
75.7\end{array}$ & $\begin{array}{r}32 \\
2154\end{array}$ & $\begin{array}{r}1.5 \\
98.5\end{array}$ & $\begin{array}{r}457 \\
1689\end{array}$ & $\begin{array}{l}21.3 \\
78.7\end{array}$ \\
\hline \multicolumn{9}{|l|}{ Pack-years } \\
\hline $\begin{array}{l}\text { Lifelong nonsmoker } \\
<20 \\
20-39 \\
\geq 40\end{array}$ & $\begin{array}{l}10 \\
59 \\
94 \\
24\end{array}$ & $\begin{array}{r}5.3 \\
31.6 \\
50.3 \\
12.8\end{array}$ & $\begin{array}{l}49 \\
96 \\
40 \\
11\end{array}$ & $\begin{array}{r}24.3 \\
47.5 \\
19.8 \\
5.4\end{array}$ & $\begin{array}{r}32 \\
455 \\
896 \\
780\end{array}$ & $\begin{array}{r}1.5 \\
20.8 \\
41.0 \\
35.7\end{array}$ & $\begin{array}{l}457 \\
839 \\
533 \\
264\end{array}$ & $\begin{array}{l}21.3 \\
39.1 \\
24.8 \\
12.3\end{array}$ \\
\hline Other tobacco products ${ }^{a}$ & - & - & 6 & 3.0 & 23 & 1.1 & 53 & 2.5 \\
\hline
\end{tabular}

a Cigars, cigarillos, and pipes only.

Table 2. Number of subjects who had, at some time, worked for at least 6 months in industries and occupations entailing known lung carcinogens (A list).

\begin{tabular}{|c|c|c|c|c|c|}
\hline \multirow{3}{*}{$\begin{array}{l}\text { Industry or occupation including } \\
\text { known carcinogens (A list) }\end{array}$} & \multicolumn{2}{|c|}{$\leq 45$ years } & \multicolumn{3}{|c|}{$55-69$ years } \\
\hline & \multirow{2}{*}{$\begin{array}{l}\text { Cases } \\
(\mathrm{N})\end{array}$} & \multirow{2}{*}{$\begin{array}{l}\text { Referents } \\
(\mathrm{N})\end{array}$} & \multirow{2}{*}{$\begin{array}{l}\text { Cases } \\
(\mathbb{N})\end{array}$} & \multicolumn{2}{|c|}{ Referents } \\
\hline & & & & N & Smokers $(\%)$ \\
\hline Agriculture or vineyard workers using arsenical insecticides & - & - & 1 & 2 & . \\
\hline Mining or iron-ore mining & - & - & 21 & 10 & . \\
\hline Asbestos production & - & - & 15 & 8 & . \\
\hline Metals or iron and steel founding & 4 & 3 & 55 & 38 & 84 \\
\hline Metals (nonferrous basic industries: smelting, alloying, .. .) & - & 1 & 30 & 19 & . \\
\hline Pickling operations, chrome plating, electroplating & - & 1 & 12 & 5 & . \\
\hline Brazing & - & - & 5 & - & - \\
\hline Shipbuilding, motor vehicle industry, railroad manufacturing workers & 11 & 4 & 141 & 98 & 82 \\
\hline Coke plant workers & - & - & 10 & 1 & \\
\hline Gas workers & - & - & 4 & 1 & . \\
\hline Insulators and pipe coverers & 2 & 1 & 22 & 9 & . \\
\hline Roofers & 5 & 1 & 22 & 21 & 95 \\
\hline Asphalt workers & 5 & 2 & 61 & 37 & 78 \\
\hline Painters & 15 & 7 & 78 & 57 & 88 \\
\hline
\end{tabular}

a ISIC codes 3841, 3842 not including motor vehicle mechanics (3843); see reference 21.

b Percentage of ever smokers, provided that the number was greater than 20 only.

struct variables in terms of total duration in years and the average and cumulative consumption of cigarettes.

\section{Statistical methods}

The individually matched cases and referents of the BIPS study and frequency matched cases and referents of the
GSF study were stratified post hoc according to the matching variables age (5-year groups) and region (17 categories). A risk analysis was carried out by means of conditional logistic regression (24), using the SAS procedure PHREG (25). We calculated odds ratios (OR) adjusted for the matching criteria age and region $\left(\mathrm{OR}_{1}\right)$, and 
Table 3. Number of subjects who had, at some time, worked for at least 6 months in industries and occupations entailing suspected lung carcinogens (B list).

\begin{tabular}{|c|c|c|c|c|c|}
\hline \multirow{3}{*}{$\begin{array}{l}\text { Industry or occupation including } \\
\text { suspected carcinogens (B list) }\end{array}$} & \multicolumn{2}{|c|}{$\leq 45$ years } & \multicolumn{3}{|c|}{$55-69$ years } \\
\hline & \multirow{2}{*}{$\begin{array}{l}\text { Cases } \\
(\mathrm{N})\end{array}$} & \multirow{2}{*}{$\begin{array}{l}\text { Referents } \\
\text { (N) }\end{array}$} & \multirow{2}{*}{$\begin{array}{l}\text { Cases } \\
(\mathrm{N})\end{array}$} & \multicolumn{2}{|c|}{ Referents } \\
\hline & & & & N & Smokers $^{b}(\%)$ \\
\hline Butchers and meat industry workers & 1 & 2 & 40 & 26 & 92 \\
\hline Leather industry or tanners and processers & - & - & 2 & 1 & \\
\hline Wood industry or carpenters and joiners & 7 & 9 & 235 & 179 & 77 \\
\hline Printing or rotogravure workers, printing pressmen and binders & 3 & 1 & 7 & 10 & . \\
\hline Occupations in the rubber manufacturing industry & 2 & 1 & 18 & 9 & \\
\hline Ceramics industry or ceramics and pottery workers & 2 & 1 & 62 & 45 & 89 \\
\hline Glass industry workers & 1 & 1 & 26 & 17 & \\
\hline Motor vehicle manufacturing industry or mechanics, welders, etc & 21 & 13 & 161 & 114 & 86 \\
\hline Transport or railroad workers, bus and truck drivers & 22 & 10 & 249 & 155 & 89 \\
\hline Operators of excavating machines & 3 & - & 33 & 8 & . \\
\hline Laundry and dry cleaners & - & - & 11 & 3 & . \\
\hline
\end{tabular}

a $I$ SIC codes 3841 ; see reference 21 .

b Percentage of ever smokers, provided that the number was greater than 20 only.

also odds ratios additionally adjusted for potential confounders. Smoking was included in all the models $\left(\mathrm{OR}_{2}\right)$ by fitting pack-years as a continuous variable $(\log ($ packyear +1$))$, type of tobacco product as a binary variable (cigarettes or other tobacco products only, ie, cigars or pipes), and time since stopping smoking as a categorical variable with 4 categories (current smoker or quit since 2 years, quit since $2-5,5-10,>10$ years). Asbestos exposure was included in the model as a continuous variable of duration of asbestos exposure in days $\left(\mathrm{OR}_{3}\right)$. The inclusion of a study-specific interaction term in the logistic model resulted in no improvement in the fitting of the regression models. We have therefore, reported only results obtained without a study-specific interaction term.

The differences in the odds ratios between the older and younger age groups were formally tested by combining the data sets of the younger and older subjects and by including, in addition to the terms exposure variable and age group, an interaction term for exposure and age group in the logistic model. A statistically significant interaction term indicated a significant difference in the odds ratios for both age groups.

\section{Results}

Slightly more young cases were lifelong nonsmokers $(5.3 \%)$ than old cases $(1.5 \%)$ (table 1$)$. This result also proved to be true for the referents ( $24.3 \%$ versus $21.3 \%$ ). Lung cancer risk for ever smokers was increased 6-fold for the young men [OR 5.5, 95\% confidence interval (95\% CI) $2.7-11.3$ ] and 19-fold for the older men (OR $18.5,95 \%$ CI $12.9-26.7$ ). However, smoking pattern was completely different in the younger and older groups of subjects with respect to duration of smoking, level of consumption, use of filter cigarettes, tar content of cigarettes smoked, and so on. An analysis on the basis of the variables duration of smoking and average or cumulative consumption of tobacco products produced significantly increased exposure-response relationships, with risk estimates not differing greatly between the older and younger men.

Table 4 presents the results for asbestos exposure. Among the older referents, $22 \%$ of the subjects had been exposed to asbestos at the workplace at some time (for at least 6 months), compared with $18 \%$ among the younger referents. The cases, however, showed differences in exposure by age. Forty percent of all the younger cases had, at some time, been subject to an occupational asbestos exposure, as compared with only $30 \%$ of the older cases. After adjustment for smoking, asbestos exposure was associated with a 2.4 -fold significantly increased lung cancer risk in the younger group, whereas, among the older age group, a 1.5-fold increased risk was observed. This difference in risk estimates was statistically significant. When duration of exposure in days was taken into account, a higher lung cancer risk at each level of exposure was established for the younger group than for the older group. The trend test for $\log$ (duration of asbestos exposure in days +1 ) proved to be statistically significant for both age groups.

The job or industry for which exposure to asbestos was reported most frequently was that of motor vehicle mechanics occupied with relining brakes or clutches $(21$ younger cases and 12 younger referents and 117 older cases and 86 older referents), followed by insulators, who sprayed asbestos insulation or worked with asbestos panels or matting (21 younger cases and 10 younger referents and 154 older cases and 85 older referents), electricians, who insulated with asbestos material, and 
Table 4. Lung cancer risk for occupational exposure to asbestos by age group. (OR = odds ratio, $95 \% \mathrm{Cl}=95 \%$ confidence interval)

\begin{tabular}{|c|c|c|c|c|c|c|c|c|c|c|}
\hline & \multicolumn{5}{|c|}{$\leq 45$ years } & \multicolumn{5}{|c|}{$55-69$ years } \\
\hline & $\begin{array}{c}\text { Cases } \\
(\mathrm{N})\end{array}$ & $\begin{array}{l}\text { Referents } \\
(\mathrm{N})\end{array}$ & $\mathrm{OR}_{1}^{\mathrm{a}}$ & $\mathrm{OR}_{2}^{\mathrm{b}}$ & $95 \% \mathrm{Cl}$ & $\begin{array}{l}\text { Cases } \\
(\mathrm{N})\end{array}$ & $\begin{array}{l}\text { Referents } \\
\text { (N) }\end{array}$ & $O R_{1}^{a}$ & $\mathrm{OR}_{2}{ }^{\mathrm{b}}$ & $95 \% \mathrm{Cl}$ \\
\hline \multicolumn{11}{|l|}{ Asbestos exposure } \\
\hline Never & 113 & 166 & 1.00 & 1.00 & & 1527 & 1670 & 1.00 & 1.00 & \\
\hline Ever & 74 & 36 & 3.08 & 2.39 & $1.41-4.04$ & 659 & 476 & 1.53 & 1.46 & $1.24-1.72$ \\
\hline \multicolumn{11}{|l|}{ Duration in days } \\
\hline Never & 113 & 166 & 1.00 & 1.00 & & 1527 & 1670 & 1.00 & 1.00 & \\
\hline $0-459$ & 25 & 12 & 2.88 & 2.45 & $1.05-5.68$ & 257 & 214 & 1.32 & 1.33 & $1.05-1.68$ \\
\hline $460-1399$ & 22 & 16 & 2.26 & 2.09 & $0.94-4.67$ & 172 & 128 & 1.48 & 1.39 & $1.05-1.84$ \\
\hline$\geq 1400$ & 27 & 8 & 4.80 & 2.72 & $1.13-6.55$ & 230 & 134 & 1.91 & 1.71 & $1.31-2.23$ \\
\hline Log(duration in days +1 ) & . & . & 1.18 & 1.13 & $1.04-1.22$ & . & 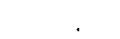 & 1.07 & 1.06 & $1.04-1.09$ \\
\hline
\end{tabular}

adjusted for age and region.

Adjusted for age, region, and $\log ($ pack-year+1), type of tobacco (binary), and time since stopping smoking.

locksmiths or tinsmiths who used sealings, mats or filters containing asbestos. In the younger age group, also roofers and dockers who had worked with asbestos materials proved to be a significant exposure group.

The subjects who had at some time worked in industries or occupations of the A list (jobs recognized to present an excess risk of lung cancer, for a detailed list see table 2), showed significantly elevated odds ratios in both age groups (table 5), being higher in the younger group with an $\mathrm{OR}_{2}$ of 2.06 (95\% CI 1.05-4.02) than in the older group $\left(\mathrm{OR}_{2} 1.33,95 \% \mathrm{CI} 1.10-1.62\right)$. Both of these odds ratios were adjusted for smoking. To obtain some measure of risk independent of asbestos-related risk, we additionally adjusted for asbestos exposure, and this adjustment resulted in slightly decreased odds ratios for both age groups. The differences in the risk estimates did not reach levels of statistical significance. In order to determine whether occupational exposure at a very young age was associated with the early onset of lung cancer, we categorized the subjects into those exposed very early ( $<16$ years of age) and late ( $\geq 16$ years of age). In the younger age group, working in a job of the $A$ list at an age of $<16$ years was associated in the first instance with an $\mathrm{OR}_{2}$ of 6.14 and an $\mathrm{OR}_{2}$ of 1.51 for subjects from the younger group who started to work later (table 5). For those in the older group who had started to work very early, no elevated risk was observed.

Elevated risk estimates were obtained for both age groups for which jobs involving known (A list) and suspected (B list) carcinogens were considered separately, with subjects who were never exposed in a job of the $A$ or B list being applied as the reference category (table 6). The workers classified under the A list exhibited, compared with the reference category "no exposure from A- or B-list jobs", a significantly increased lung cancer risk in both age groups, independently of asbestos exposure. Lung cancer risk was twice as high among the younger subjects than the older subjects if they had worked for longer than 15 years in a job included in the A or B list. The odds ratios for men who had started to

Table 5. Lung cancer risk for jobs entailing exposure to known lung carcinogens (A list) by age group. ( $\mathrm{OR}=$ odds ratio, $95 \% \mathrm{Cl}=95 \%$ confidence interval)

\begin{tabular}{|c|c|c|c|c|c|c|c|c|c|c|c|c|}
\hline \multirow[t]{2}{*}{ Exposure to $\mathrm{A}$ list } & \multicolumn{6}{|c|}{$\leq 45$ years } & \multicolumn{6}{|c|}{$55-69$ years } \\
\hline & $\begin{array}{l}\text { Cases } \\
\text { (N) }\end{array}$ & $\begin{array}{l}\text { Referents } \\
\text { (N) }\end{array}$ & $O R_{1}{ }^{a}$ & $\mathrm{OR}_{2}^{\mathrm{b}}$ & $\mathrm{OR}_{3}{ }^{\mathrm{c}}$ & $95 \% \mathrm{Cl}$ & $\begin{array}{l}\text { Cases } \\
\text { (N) }\end{array}$ & $\begin{array}{l}\text { Referents } \\
\text { (N) }\end{array}$ & $\mathrm{OR}_{1}^{\mathrm{a}}$ & $\mathrm{OR}_{2}^{\mathrm{b}}$ & $O R_{3}{ }^{c}$ & $95 \% \mathrm{Cl}$ \\
\hline Never A & 149 & 182 & 1.00 & 1.00 & 1.00 & . & 1760 & 1861 & 1.00 & 1.00 & 1.00 & \\
\hline Ever A & 38 & 20 & 2.24 & 2.06 & 1.84 & $0.94-3.63$ & 426 & 285 & 1.57 & 1.33 & 1.24 & $1.02-1.50$ \\
\hline \multicolumn{13}{|c|}{ Duration of exposure in years } \\
\hline$<15$ years $\mathrm{m}$ & 23 & 13 & 2.10 & 2.22 & 1.89 & $0.82-4.37$ & 275 & 192 & 1.50 & 1.38 & 1.30 & $1.02-1.63$ \\
\hline$\geq 15$ years & 15 & 7 & 2.47 & 1.83 & 1.80 & $0.61-5.14$ & 151 & 93 & 1.70 & 1.26 & 1.19 & $0.84-1.56$ \\
\hline \multicolumn{13}{|c|}{ Age at start of work in an A-list job } \\
\hline$<16$ years & 14 & 3 & 5.43 & 6.14 & 5.52 & $1.27-23.28$ & 116 & 90 & 1.37 & 1.19 & 1.12 & $0.80-1.54$ \\
\hline$\geq 16$ years & 24 & 17 & 1.66 & 1.51 & 1.34 & $0.59-2.78$ & 310 & 195 & 1.67 & 1.40 & 1.34 & $1.03-1.63$ \\
\hline
\end{tabular}

adjusted for age and region.

${ }^{\circ}$ Adjusted for age, region and log(pack-year+1), type of tobacco, and time since stopping smoking.

c Adjusted for age, region and $\log$ (pack-year+1), type of tobacco, time since stopping smoking, and asbestos exposure. 
Table 6. Lung cancer risk for jobs entailing exposure to known or suspected lung carcinogens ( $A$ or $B$ list) by age group. (OR $=$ odds ratio, $95 \% \mathrm{Cl}=95 \%$ confidence interval)

\begin{tabular}{|c|c|c|c|c|c|c|c|c|c|c|c|c|}
\hline \multirow{2}{*}{$\begin{array}{l}\text { Exposure to } \mathrm{A} \\
\text { or } \mathrm{B} \text { list }\end{array}$} & \multicolumn{6}{|c|}{$\leq 45$ years } & \multicolumn{6}{|c|}{$55-69$ years } \\
\hline & $\begin{array}{c}\text { Cases } \\
(\mathrm{N})\end{array}$ & $\begin{array}{l}\text { Referents } \\
\text { (N) }\end{array}$ & $O R_{i}^{a}$ & $O R_{2}{ }^{\prime \prime}$ & $\mathrm{OR}_{3}^{\mathrm{g}}$ & $95 \% \mathrm{Cl}$ & $\begin{array}{l}\text { Cases } \\
(\mathrm{N})\end{array}$ & $\begin{array}{l}\text { Referents } \\
\text { (N) }\end{array}$ & $\mathrm{OR}_{1}^{\mathrm{a}}$ & $O R_{2}^{b}$ & $O R_{3}{ }^{c}$ & $95 \% \mathrm{Cl}$ \\
\hline $\mathrm{B}$, never A & 38 & 26 & 2.14 & 2.15 & 1.72 & $0.87-3.41$ & 563 & 403 & 1.72 & 1.40 & 1.35 & $1.13-1.61$ \\
\hline Ever A & 38 & 20 & 2.56 & 2.36 & 2.06 & $1.03-4.12$ & 426 & 285 & 1.81 & 1.46 & 1.35 & $1.10-1.65$ \\
\hline \multicolumn{13}{|c|}{ Duration of exposure in an A- or B-list job } \\
\hline$<15$ years $(A$ or $B)$ & 35 & 28 & 1.79 & 1.84 & 1.48 & $0.77-2.95$ & 489 & 371 & 1.59 & 1.37 & 1.31 & $1.08-1.56$ \\
\hline$\geq 15$ years $(A$ or $B)$ & 41 & 18 & 3.12 & 2.79 & 2.39 & $1.18-4.84$ & 500 & 317 & 1.94 & 1.49 & 1.42 & $1.17-1.70$ \\
\hline \multicolumn{13}{|c|}{ Age at start of work in an A- or B-list job } \\
\hline$<16$ years $(A$ or $B)$ & 26 & 16 & 2.36 & 2.23 & 1.78 & $0.79-4.03$ & 372 & 292 & 1.57 & 1.41 & 1.34 & $1.08-1.63$ \\
\hline$\geq 16$ years $(A$ or $B)$ & 50 & 30 & 2.31 & 2.26 & 1.89 & $1.05-3.57$ & 617 & 396 & 1.89 & 1.44 & 1.40 & $1.15-1.63$ \\
\hline
\end{tabular}

adjusted for age and region.

adjusted for age, region and log(pack-year+1), type of tobacco, and time since stopping smoking.

c Adjusted for age, region and log(pack-year +1$)$, type of tobacco, time since stopping smoking, and asbestos exposure.

work at a very early age in such jobs did not differ from those who had started later, regardless of their age group.

In table 2 the numbers of subjects working in jobs and industries included in the A list are given in detail. High risk groups were subjects working in industries related to ship building and motor vehicles and also railroad manufacturing workers with an $\mathrm{OR}_{2}$ of $5.10(95 \%$ CI 1.26-20.62) for the younger group as compared with an $\mathrm{OR}_{2}$ of 1.38 (95\% CI 1.00-1.89) for the older group. Second, roofers from the younger group showed an elevated risk $\left(\mathrm{OR}_{2} 4.67,95 \%\right.$ CI $\left.0.42-52.42\right)$, followed by painters $\left(\mathrm{OR}_{2} 2.00,95 \% \mathrm{CI} 0.73-5.52\right)$. These odds ratios were adjusted for smoking. The most frequently reported jobs from the B list (table 3 ) were those of bus and truck drivers $\left(\mathrm{OR}_{2} 2.67,955 \mathrm{CI} 1.08-6.58\right.$, in the younger group and $\mathrm{OR}_{2} 1.22,95 \% \mathrm{CI} 0.96-1.56$, in the older group). A second large group of exposed subjects was formed by mechanics and welders in the motor vehicle manufacturing industry in both age groups. In the older group, additionally, those working in the wood industry, carpenters and joiners, represented frequently reported affected occupations. The percentage of ever smokers among the older referents working in jobs belonging to the A or B list were slightly higher (84\%) than among those having never worked in such jobs $(76 \%)$. This result also proved to be true for younger referents ( $80 \%$ and $74 \%$, respectively).

\section{Discussion}

Occupational risk factors for lung cancer at a young age have not been investigated in detail, since in general the numbers of early onset lung cancer patients are small. Our pooled study had the advantage of including a relatively large sample size of young subjects. Since in both case-referent studies a comparable method of data collection with nearly identical questionnaires on lifelong occupations, smoking habits and the same 20 job-specific supplementary questionnaires were used, a detailed exposure quantification of occupational risk factors was possible.

Our results demonstrated that occupational risk factors play an important role for lung cancer at a young age. Occupational exposure to certain substances (such as asbestos exposure) and working in certain occupations (such as insulator, roofer, painter, motor vehicle mechanic) and industries (shipbuilding) which are known to be associated with an increased lung cancer risk $(26,27)$ were confirmed in the present analysis of young workers. Occupations like those of bus and truck drivers, which still prove to be controversial with regard to their causal role in the development of lung cancer, provide some evidence for an increased lung cancer risk among younger men, possibly because of exposure to diesel engine exhaust.

The odds ratios for all the investigated occupational exposures, and at all exposure levels, were consistently higher in the group of younger men than in the group of older men. Some of these differences proved to lack statistical significance when an interaction term was formally tested. Lung cancer risk due to asbestos exposure was, however, nearly twice as high among the younger men than among the older men, with a statistically significant difference for the risk estimates. The percentage of referents who had at some time been exposed to asbestos was slightly lower in the younger group (18\%) than in the older group (22\%). This result was to be expected since the first possible year of exposure to asbestos among the younger group could be in the 1970 s at the earliest, and then in Germany there was a significant decrease in the use of asbestos after 1980 (28). It is therefore remarkable that more younger cases were exposed to asbestos $(40 \%)$ than older cases $(30 \%)$.

The interpretation of the age-dependent differences in lung cancer risk by occupation is not easy. Possibly, 
relative risks for specific agents can be more clearly observed at younger ages when the absolute disease rate is low, while at older ages the higher background rates of chronic diseases make the relative effect of a single agent harder to detect. Therefore even significant differences in the relative risk estimates may only describe an increased visibility of exposure effects owing to lower background rates among the younger subjects.

On the other hand, our results provide some evidence that exposure at an early age may favor an early age for the onset of lung cancer. More younger patients started work in a job entailing exposure to known carcinogens at an early age than older cases. This finding is surprising, since the younger generation started in general to work at a later stage than the older generation due to a longer period of schooling. Early onset of exposure was associated with a 6-fold increased lung cancer risk in the younger group, whereas no elevated risk was detected for the older group. This lack of any effect among the older subjects may be due to the fact that those who were prone to get cancer had already got it earlier. Moreover, since it was not quite clear whether the increased risk of the younger subjects was really due to the age at first exposure or may not rather have been influenced by a longer duration of exposure, we additionally adjusted for duration, and the results remained nearly unchanged (eg, $\mathrm{OR}_{2}$ $6.69,95 \%$ CI $1.09-41.71$, for subjects who started to work at an early age in a job of the A list in the younger group).

Higher risk estimates of occupational exposure for the young might also suggest a combined effect of smoking and occupation in that, once there are 2 exposures, cancer tends to appear earlier. To investigate such an effect, we repeated the risk analyses stratified by different levels of cumulative tobacco consumption $(<5,5-20,20$ $40,>40$ pack-years), and the risk of asbestos exposure, for example, remained 2-fold higher among the younger subjects than among the older ones at each level of tobacco consumption. Therefore, an effect of occupational exposure on its own seems very likely.

A more speculative hypothesis for the early age of onset of lung cancer is that of a population of susceptibles, which develops cancer much more quickly. In a previous analysis (7) we found a high familial risk of lung cancer only in the younger group ( $\leq 45$ years) with an OR of $2.6(95 \% \mathrm{CI} 1.1-6.0)$ and no elevated risk for the older subjects (55-69 years) (OR 1.2, 95\% CI 0.9-1.6); this finding indicated a genetic predisposition among the younger patients. It is possible that several susceptible genes exist that modify risk in the presence of environmental carcinogens. Such an effect has been reported for smoking as an environmental carcinogen in the early-onset lung cancer patients of Sellers et al $(9,29)$. In segregation analyses, he and his colleagues demonstrated that the pattern of lung cancer occurrence in families was consistent with Mendelian co-dominant inheritance of a rare autosomal gene that produces an earlier age of onset of cancer. They suggested that inherited susceptibility is expressed only in the presence of tobacco smoking.

A particular strength of this study is that all the subjects were interviewed in person; no data were obtained from next-of-kin or other surrogates. We used a detailed lifelong description of all occupations and industries in which a study subject had ever been employed for a period of at least 6 months. Exposure to asbestos was not inferred by self-report, but rather on the basis of job and industry titles and extensive, standardized, job-specific, supplementary questionnaires [eg, for motor vehicle mechanics, who were asked whether they had ever relined brakes or clutches using special asbestos products (a list of products was provided)]. Further details of this procedure have been described elsewhere $(14,22,23)$. Special attention was given to the main confounder smoking by testing several models. The combination of the variables pack-year, type of tobacco, and years since the subject stopped smoking showed the best fit in comparison with other models for smoking. Smoking did not in fact prove to be a particularly strong confounder, since there were rather small differences between $\mathrm{OR}_{1}$ and $\mathrm{OR}_{2}$.

As the referents tended to be more highly educated than the cases and there is a correlation between social class and occupational exposure, special attention was given to a potential selection bias. The low response received from potential referents in the GSF study was investigated with a nonresponse analysis on a subsample of refusals. Nonresponse was mainly attributable to refusals for long-term ( 1 year) measurements of radon required for the study in the bedroom and living room of the subject's home. A comparison of data on the years of school attendance of men aged 30-45 years in Germany in 1992, based on official statistics (1), with the corresponding data for the group of younger participating referents revealed slight differences only (the levels for $<10,10-11, \leq 12$ years of school attendance being $45 \%, 29 \%$, and $26 \%$ in the official statistics and $40 \%$, $27 \%$, and $33 \%$ for the young participating referents, respectively). Additional adjustment for school attendance showed some decrease in the odds ratios, but the overall pattern of lung cancer risk estimates in both age groups remained [eg, OR values for ever exposure to asbestos in the young (OR 1.91, 95\% CI 1.08-3.23) and the older (OR 1.32, 95\% CI 1.13-1.58) groups]. On the other hand, it must be mentioned that adjustment for social class may lead to overadjustment, and it thus can artificially reduce the estimated risk of occupational exposures.

In conclusion, young cases are a particularly interesting population to study. The results of the study demonstrated that occupational exposure plays a very 
important role in lung cancer at a young age. There is also some evidence to suggest that exposure at an early age may favor the onset of lung cancer at an early age.

\section{Acknowledgments}

This report was financially supported by Bundesministerium für Bildung, Wissenschaft, Forschung und Technologie (BMBF), Bonn (grant no: 0m1 HK 1730).

\section{References}

1. Statistisches Bundesamt. Statistisches Jahrbuch 1994. Wiesbaden: Metzler-Poeschel, 1995.

2. Icard P, Regnard JF, de Napoli S, Rojas Miranda A, Dartevelle P, Levasseur P. Primary lung cancer in young patients: a study of 82 surgically treated patients. Ann Thorac Surg 1992;54:99-103.

3. Tsugane S, Watanabe S, Sugimura H, Arimoto H, Shimosato Y, Suemasu K. Smoking, occupation and family history in lung cancer patients under fifty years of age. Jpn J Clin Oncol 1987;17:309-17.

4. Bourke W, Milstein D, Giura R, Donghi M, Luisetti M, Rubin $\mathrm{AH}$, et al. Lung cancer in young adults. Chest 1992;102:1723-9.

5. Rocha MP, Fraire AE, Guntupalli KK, Greenberg SD. Lung cancer in the young. Cancer Detect Prev 1994;18:349-55.

6. Jubelirer SJ, Wilson RA. Lung cancer in patients younger than 40 years of age. Cancer 1991;67:1436-8.

7. Kreuzer M, Kreienbrock L, Gerken M, Heinrich J, BrüskeHohlfeld I, Müller KM, et al. Risk factors for lung cancer in young adults. Am J Epidemiol 1998;147:1028-37.

8. Schwartz AG, Yang P, Swanson M. Familial risk of lung cancer among nonsmokers and their relatives. Am J Epidemiol 1996;144:554-62.

9. Sellers TA, Potter JD, Bailey Wilson JE, Rich SS, Rothschild $\mathrm{H}$, Elston RC. Lung cancer detection and prevention: evidence for an interaction between smoking and genetic predisposition. Cancer Res 1992;52:2694s-7s.

10. Doll R, Peto R. The causes of cancer: quantitative estimates of avoidable risks in the United States today. JNCI 1981;66:1191-308

11. Joeckel K-H, Ahrens W, Bolm-Audorff U, Jahn I, Pohlabeln $\mathrm{H}$. Beruflich verursachter Lungenkrebs - eine quantitative Abschätzung für den norddeutschen Raum. Gesundheitswesen 1997:59:275-8.

12. Jöckel KH, Ahrens W, Jahn I, Pohlabeln H, Bolm-Audorff U. Occupational risk factors for lung cancer: results of a casecontrol study in West Germany. Int J Epidemiol 1998;27:549-60.

13. Kreienbrock L, Wichmann H-E, Gerken M, Heinrich J, Goetze H-J, Kreuzer M, et al. The German radon project — feasibili- ty of methods and first results. Rad Prot Dos 1992;45:643 — 9 .

14. Ahrens W, Jöckel KH, Brochard P, Bolm-Audorff U, Grossgarten $\mathrm{K}$, Iwatsubo $\mathrm{Y}$, et al. Retrospective assessment of asbestos exposure, I: case-control analysis in a study of lung cancer: efficiency of job-specific questionnaires and job-exposure matrices. Int J Epidemiol 1993;22:83-95.

15. Statistisches Bundesamt. Systematik der Wirtschaftszweige mit Erläuterungen. Stuttgart: Kohlhammer Verlag, 1979.

16. Bundesanstalt für Arbeit. Klassifizierung der Berufe, Systematisches und alphabetisches Verzeichnis der Berufsbenennungen. Stuttgart: Kohlhammer Verlag, 1975.

17. United Nations. International standard industrial classification of all economic activities (ISIC). New York (NY): Publishing Service United Nations, 1971. United Nations publications ST/STAT/M.4/Rev.2/Add.1, Sales No: E.71.XVIL8, 1971.

18. International Labour Organisation (ILO). International stand ard classification of occupations (ISCO, Revised 1968). Geneva: ILO, 1968.

19. Simonato L, Saracci R. Cancer, occupational. Geneva: International Labour Organisation, 1983:369—75.

20. Boffetta P, Kogevinas M, Simonato L, Wilbourn J, Saracci R. Current perspectives on occupational cancer risks. Int J Occup Environ Health 1995;1:315-25.

21. Ahrens W, Merletti F. A standard tool for the analysis of occupational lung cancer in epidemiological studies. Int J Occup Environ Health 1998;4:236-40.

22. Ahrens W, Jöckel KH, Pohlabeln H, Bolm-Audorff U, Iwat subo Y, Brochard P, et al. Assessment of exposure to asbestos in a case-control study of lung cancer: comparison of supplementary questionnaires and an exposure check-list. Occup Hyg 1996;3:125-36.

23. Orlowski E, Pohlabeln H, Berrino F, Ahrens W, Bolm-Audorff $\mathrm{U}$, Grossgarten $\mathrm{K}$, et al. Retrospective assessment of asbestos exposure, II: at the job level: complementarity of job-specific questionnaire and job exposure matrices. Int J Epidemiol 1993;22:96-105.

24. Breslow NE, Day NE. Statistical methods in cancer research; vol 1 (The analysis of case-control-studies). Lyon: International Agency for Research on Cancer, 1980:248-79.

25. SAS Institute Inc. SAS/STAT user's guide. Cary (NC): SAS Institute, 1989.

26. Rinsky RA, Melius JM, Hornung RW. Case-control study of lung cancer in civilian employees at the Portsmouth Naval Shipyard. Am J Epidemiol 1988;127:55-64.

27. Partanen T, Boffetta P. Cancer risk in asphalt workers and roofers; review and meta-analysis of epidemiological studies. Am J Ind Med 1994;26:721—40.

28. Bauer HD, Blome H, Blome O. Faserjahre. Berufsgenossenschaftliche Hinweise zur Ermittlung der kumulativen Asbestfaserstaub-Dosis am Arbeitsplatz (Faserjahre) und Bearbeitungshinweis zur Berufskrankheit Nr. 410 (Lungenkrebs). Rheinbreitenbach: Druckerie Plump KG, 1994.

29. Sellers TA, Potter JD, Bailey Wilson JE, Rich SS, Rothschild $\mathrm{H}$, Elston RC. Lung cancer detection and prevention: evidence for an interaction between smoking and genetic predisposition. Cancer Res 1992;52:2694s-7s.

Received for publication: 17 December 1998 